Brit. J. vener. Dis. (1963), 39, 37.

\title{
ENHANCEMENT BY LYSOZYME OF THE SENSITIVITY \\ OF TREPONEMA PALLIDUM IMMOBILIZATION TESTS*
}

\author{
BY \\ J. F. KENT AND J. B. DE WEERDT \\ Division of Laboratories and Research, New York State Department of Health, Albany, N.Y.
}

The addition of lysozyme to the survival medium has been shown (Metzger, Hardy, and Nell, 1961) to increase the rate of immobilization of Treponema pallidum by syphilitic serum and complement; this might allow $T$. pallidum immobilization (TPI) tests to be completed in a working day. But, more important from the point of view of diagnosis, was the possibility of increasing the sensitivity of the standard 18-hr TPI test and, perhaps also, of the already highly sensitive 40-hr test (Rosenau and Kent, 1958; Kent and DeWeerdt, 1961).

\section{Materials and Methods}

Treponemal Survival Medium.-The medium adopted contained the originally described ingredients (Nelson and Diesendruck, 1951) plus streptomycin (Borel, Bentejac, and Durel, 1958), penicillinase, and lysozyme; the sodium thioglycollate concentration was half that used in the initial studies of lysozyme, and bovine plasma fraction $\mathrm{V}$ was used instead of gelatin (Metzger and others, 1961). It was composed as follows:

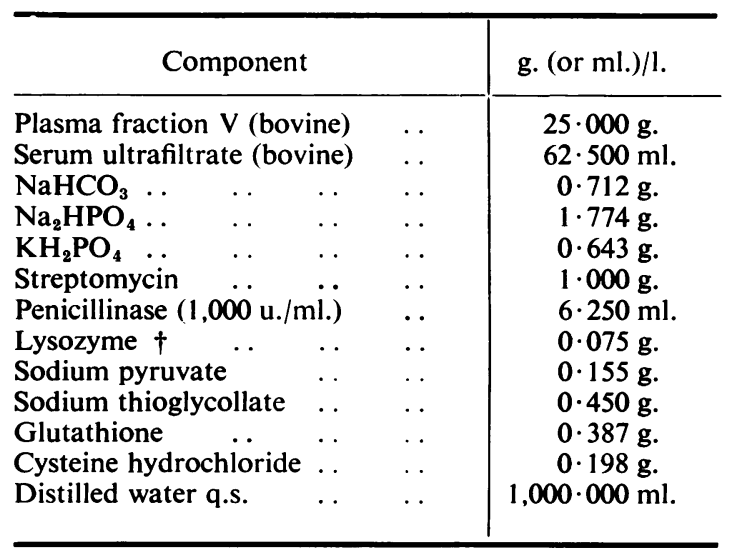

* Received for publication August 8, 1962

† Crystalline (egg white), B grade, California Corp. for Biochemical Research, Los Angeles 63, California.
The $\mathrm{pH}$ was adjusted to $7 \cdot 0 \pm 0 \cdot 02$, and the solution sterilized by filtering through a Millipore membrane of $0.45 \mu$ porosity. Forty $\mathrm{ml}$. volumes were shell frozen in 100-ml. heavy glass ampoules, and desiccated under reduced pressure. The ampoules were sealed hermetically under vacuum and stored at $-25^{\circ} \mathrm{C}$. For use they were rehydrated with $40 \mathrm{ml}$. sterile 0.59 per cent. $\mathrm{NaCl}$ solution. The concentration of the rehydrating solution represents the sum of the $\mathrm{NaCl}$ amounts used originally (Nelson and Diesendruck, 1951); the salt was not added before desiccation because it lowered the freezing point of the medium enough to cause melting before desiccation was complete.

TPI Procedure.-The standard procedure was followed (Nelson and Diesendruck, 1951; Rosenau and Kent, 1958; Kent and DeWeerdt, 1961) except that the volumes of serum, antigen, and complement $\left(C^{\prime}\right)$ were $0.05,0.375$ and $0.075 \mathrm{ml}$; five parts of antigen and one part of $C^{\prime}$ were mixed and added as $0.45 \mathrm{ml}$. Human and rabbit sera were heated 30 mins. at $56^{\circ} \mathrm{C}$. to inactivate native $\mathrm{C}^{\prime}$. For titrations they were diluted serially in 0.85 per cent. $\mathrm{NaCl}$ solution, and each dilution was tested with antigen and active guinea-pig $\mathrm{C}^{\prime}$; the lowest dilution was tested as control with antigen and heated $C^{\prime}$. Nonsyphilitic human sera were included as controls, and provided indices both of treponemal survival and specificity of the reaction. After $18 \mathrm{hrs}$ ' anaerobic incubation, a loopful (about $0.01 \mathrm{ml}$.) was removed from each tube, and the percentage of motile treponemes determined by dark-field microscopic examination. Five hundredths $\mathrm{ml}$. of active and heated $C^{\prime}$ respectively were then added to tests and controls, and the mixtures re-incubated. At $40 \mathrm{hrs}$ the percentages of motile treponemes were redetermined, and the 18-hr and 40-hr readings converted (Nelson and Diesendruck, 1951) to percentage specific immobilization. Results of qualitative tests were 
represented (Nelson, Zheutlin, Diesendruck, and Austin, 1950) as reactive (more than 50 per cent. specific immobilization), weakly reactive (21 to 50 per cent.), or non-reactive ( 0 to 20 per cent.). Titres of reactive sera were determined by plotting percentage specific immobilization on arithmetic coordinates against the $\log$ of the reciprocal of the serum dilution, and fitting a smooth sigmoid curve to the points. Titre was expressed as the reciprocal of the serum dilution causing 50 per cent. immobilization; it did not take into account the final 10 -fold dilution of serum in test reagents ( $c f$. Nelson and Diesendruck, 1951; Nelson and others, 1950).

\section{Results}

Titrations of syphilitic human and rabbit control sera, using treponemes suspended in medium without and with added 0.0075 per cent. lysozyme, are represented in the Figure. Percentage specific treponemal immobilization was consistently increased in the titrations with added enzyme.

50 per cent. immobilization titres obtained with these sera in titrations using different lots of medium and $\mathrm{C}^{\prime}$ are given in Table I (opposite); they indicate numerically the increases in sensitivity obtainable with lysozyme in tests incubated for 18 or $40 \mathrm{hrs}$.

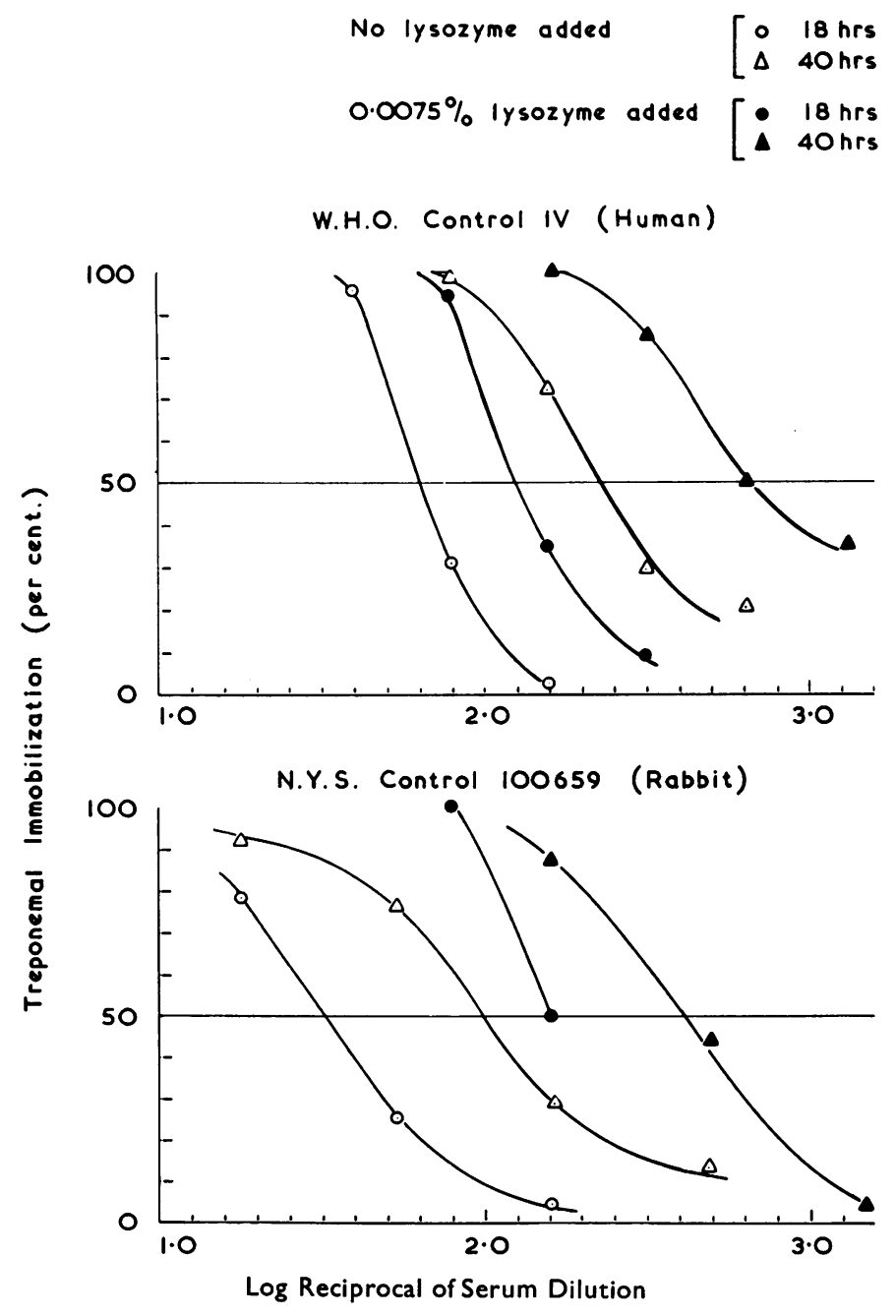

FIgURE.-Titration of syphilitic human and rabbit control sera, using treponemes suspended in medium with and without added lysozyme, at 18 and $40 \mathrm{hrs}$. 
TABLE I

TITRES OF SYPHILITIC CONTROL SERA WITHOUT AND WITH 0.0075 PER CENT. ADDED LYSOZYME

\begin{tabular}{|c|c|c|c|c|c|}
\hline \multirow{2}{*}{ Serum } & \multirow{2}{*}{ Date Tested } & \multicolumn{4}{|c|}{ Titre* } \\
\hline & & \multicolumn{2}{|c|}{ Without } & \multicolumn{2}{|c|}{ With } \\
\hline$\underset{\text { (Human) }}{\text { WHO IVt }}$ & 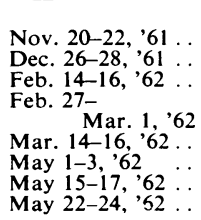 & $\begin{array}{c}18 \mathrm{hrs} \\
87 \\
47 \\
63 \\
44 \\
= \\
= \\
=\end{array}$ & $\begin{array}{c}40 \mathrm{hrs} \\
240 \\
178 \\
135 \\
120 \\
= \\
=\end{array}$ & $\begin{array}{l}18 \mathrm{hrs} \\
- \\
- \\
\overline{110} \\
282 \\
229 \\
191\end{array}$ & $\begin{array}{l}40 \mathrm{hrs} \\
- \\
- \\
\overline{214} \\
575 \\
631 \\
363\end{array}$ \\
\hline & Mean & 60 & 168 & 203 & 446 \\
\hline $\begin{array}{l}\text { NYS 100659 } \\
\text { (Rabbit) }\end{array}$ & $\begin{array}{l}\text { Mar. 6-8, '62 } 62 . \\
\text { Mar. } 21-23, ' 62 \ldots \\
\text { Mar. 28-30, } 62 \ldots \\
\text { Apr. } 24-26,62 \ldots \\
\text { May } 8-10,62 \ldots\end{array}$ & $\frac{\overline{31}}{20}$ & $\frac{\overline{162}}{66}$ & $\frac{\frac{105}{105}}{98}$ & $\frac{246}{550} \frac{1}{427}$ \\
\hline & Mean $\quad$. & 26 & 114 & 103 & 408 \\
\hline
\end{tabular}

* Reciprocal of serum dilution producing 50 per cent. immobilization.

† Distributed by the World Health Organization Serological Reference Centre, Statens Seruminstitut, Copenhagen.

$\ddagger$ Standard of the Division of Laboratories and Research, New York State Department of Health, Albany, N.Y.

To supplement these findings, human sera that had been found negative or weakly reactive in qualitative TPI tests without lysozyme were reexamined with added enzyme. The results, which demonstrate the efficacy of lysozyme in detecting threshold concentrations of treponemal immobilizing antibody, are summarized in Table II.

Of twenty specimens that had been negative at $18 \mathrm{hrs}$, five remained negative at $18 \mathrm{hrs}$, but six became weakly reactive, and nine were reactive; of thirteen originally found weakly reactive in the same circumstances, three remained weakly reactive (but with percentage treponemal immobilization increased in the given range), and ten became reactive. Sensitivity at $40 \mathrm{hrs}$ was correspondingly increased. Of six sera initially found weakly reactive after this incubation period, one remained weakly reactive (but

TABLE II

RELATIVE SENSITIVITY OF QUALITATIVE 18-HR and 40-HR TREPONEMAL IMMOBILIZATION TESTS CONDUCTED WITHOUT AND WITH ADDED LYSOZYME

\begin{tabular}{|c|c|c|c|c|}
\hline \multirow{3}{*}{ Result } & \multicolumn{4}{|c|}{$\begin{array}{c}\text { Numbers of Sera yielding Given Result } \\
\text { under Given Conditions }\end{array}$} \\
\hline & \multicolumn{2}{|c|}{$18 \mathrm{hrs}$} & \multicolumn{2}{|c|}{$40 \mathrm{hrs}$} \\
\hline & Without & With & Without & With \\
\hline Negative. & 20 & 5 & 4 & - \\
\hline Weakly Reactive & 13 & 9 & 6 & 1 \\
\hline Reactive .. & - & 19 & 23 & 32 \\
\hline
\end{tabular}

with percentage immobilization increased), and five became unequivocally reactive. Unfortunately, the number (33) of specimens available for comparative tests was limited because sera of threshold antibody content occur infrequently in diagnostic practice. However, there was no exception to the rule that reactivity was increased in the presence of added enzyme.

\section{Discussion}

Preliminary trials with the suggested medium (Metzger and others, 1961), containing twice the original concentration (Nelson and Diesendruck, 1951) of sodium thioglycollate, gelatin instead of plasma fraction $\mathrm{V}$, and $\mathbf{0 . 0 1 5}$ per cent. added lysozyme, were only partially successful. At $18 \mathrm{hrs}$, specific treponemal immobilization was significantly increased and treponemal survival was satisfactory, but at 40 hrs survival was less than the accepted 70 per cent. (Nelson and Diesendruck, 1951), making it impossible to estimate percentage specific immobilization. Since it was important to realize, if possible, the increase in sensitivity afforded by prolonging incubation, the same amount of lysozyme $(0.015$ per cent.) was incorporated in a medium (Nelson and Diesendruck, 1951; Borel and others, 1958) known to yield satisfactory 40-hr results (Rosenau and Kent, 1958; Kent and DeWeerdt, 1961). This somewhat improved treponemal survival, but $40-\mathrm{hr}$ motility remained less than 70 per cent. in about one-third of trials. Consistently satisfactory results were not achieved until the lysozyme concentration was halved $(0.0075$ per cent.). This concentration was adopted; it appeared unnecessarily time-consuming and expensive to determine the optimum more precisely. The resultant 2- to 4-fold increase in sensitivity for treponemal antibody, superimposed on that realized by prolonging incubation to $40 \mathrm{hrs}$, made the mean overall titre increase 7 - to 8 -fold in the case of an international control serum (human), and 15- to 16fold in that of a state control serum (rabbit) (see Table I). A corresponding increase in sensitivity was achieved also in qualitative diagnostic TPI tests (Table II).

Some side-effects of added lysozyme are worth noting. The elution of treponemes from syphilomatous testes was greatly accelerated, and the yield of organisms markedly increased. Infectivity for rabbits, however, was impaired, animals injected intratesticularly with the usual number of treponemes $\left(10^{8} /\right.$ testis) failing to develop orchitis within the interval (7 to 9 days) accepted for TPI tests; apparently organisms treated with lysozyme are more susceptible to the normal defence mechanisms of the host. It was 
also noted that, in qualitative TPI tests, the treponemicidal (immobilizing) effect occasionally progressed to treponemalysis (Metzger and others, 1961). A similar lysozyme-activated progression has been reported (Amano, Inai, Seki, Kashiba, Fujikawa, and Nishimura, 1954; Inoue, Tanigawa, Takubo, Satani, and Amano, 1959) in the case of Escherichia coli. The effect was ordinarily restricted to qualitative tests of undiluted, strongly reactive sera; it was not encountered in titrations beginning with relatively high serum dilutions (WHO and NYS controls). While it reduced the number of organisms available for microscopic enumeration, it was an occasional difficulty, not considered serious enough to contraindicate the use of lysozyme.

A similar study (Fribourg-Blanc, 1962) has been published while this report was being prepared. Lysozyme was found to increase sensitivity 3-fold, not only over short incubation periods but over the standard 20- to 22-hr period for TPI tests. This finding, like ours, was at variance with that of the original investigators (Metzger and others, 1961) and was recognized as having obvious applications in serodiagnosis. The observed maximally-enhancing concentration, $100 \mu \mathrm{g} . / \mathrm{ml}$. medium, and toxic concentration, $400 \mu \mathrm{g} . / \mathrm{ml}$., were in close agreement with those originally established (Metzger and others, 1961). However, a concentration of $200 \mu \mathrm{g}$. $/ \mathrm{ml}$. medium was adopted for diagnostic TPI tests. As indicated by our experience, concentrations of this order are toxic when incubation is extended beyond $18 \mathrm{hrs}$, and this may have discouraged attempts to achieve a more sensitive 40-hr test.

\section{Summary}

The incorporation of 0.0075 per cent. lysozyme in treponemal survival medium effects a 3- to 4-fold increase in the sensitivity of tests for specific $T$. pallidum immobilizing (TPI) antibody. This increase, superimposed on that achieved by incubating for $\mathbf{4 0}$ hrs instead of the usual $18 \mathrm{hrs}$, resulted respectively in 7- to 8-fold and 15- to 16-fold mean increases in the titres of syphilitic human and rabbit sera. Practical applications in the sero-diagnosis of syphilis are demonstrated.

\section{REFERENCES}

Amano, T., Inai, S., Seki, Y., Kashiba, S., Fujikawa, K., and Nishimura, S. (1954). Med. J. Osaka Univ., 4, 401 .

Borel, L. J., Bentejac, R., and Durel, P. (1958). Brit. J. vener. Dis., 34, 241.

Fribourg-Blanc, A. (1962). Ann. Inst. Pasteur, 102, 460.

Inoue, K., Tanigawa, Y., Takubo, M., Satani, M., and Amano, T. (1959). Biken's J., 2, 1.

Kent, J. F., and De Weerdt, J. B. (1961). Amer. J. clin. Path., 35, 526.

Metzger, M., Hardy, P. H., Jr., and Nell, E. E. (1961). Amer. J. Hyg., 73, 236.

Nelson, R. A., Jr., and Diesendruck, J. A. (1951). J. Immunol., 66, 667.

- Zheutlin, H. E. C., Diesendruck, J. A., and Austin, P. G. M. (1950). Amer. J. Syph., 34, 101.

Rosenau, B. J., and Kent, J. F. (1958). J. Lab. clin. Med., 51,664 .

Augmentation par lysozyme de la sensibilité du test d'immobilization des tréponèmes (T.P.I.)

\section{RÉSUMÉ}

L'addition de $0,0075 \%$ lysozyme au milieu de survie des tréponèmes augmente de trois ou quatre fois la sensibilité des tests spécifiques de l'anticorps immobilisant les tréponèmes.

Cette augmentation, ajoutée à celle obtenue par incubation de $\mathbf{4 0}$ heures au lieu de 18 heures, fait monter le titre moyen des sérums syphilitiques de 7 à 8 fois chez l'homme et de 15 à 16 fois chez le lapin.

Ou décrit l'application pratique de cette méthode dans le diagnostic de la syphilis. 